\title{
Transformacja gospodarcza jako marginalizacja. Gospodarcze i społeczne skutki polskiego czasu przemian
}

Jerzy Klimczak | Wydział Nauk Społecznych, Uniwersytet Gdańsk

\section{Streszczenie}

Słowa kluczowe:

transformacja

ustrojowa, teoria systemów-światów,

Immanuel

Wallerstein,

gospodarka

political

transformation

world-system

analysis,

Immanuel

Wallerstein,

economy

Artykuł przedstawia interpretację procesu transformacji gospodarczej w Polsce w ujęciu teorii systemów-światów Immanuela Wallersteina. Głównym założeniem tekstu jest przyjęcie, że neoliberalna droga przemian wpłynęła na marginalizację Polski na arenie międzynarodowej poprzez przywrócenie jej półperyferyjnego statusu. Analizie zostały poddane trzy czynniki mogące świadczyć o półperyferyjnej pozycji Polski. Po pierwsze, struktura własności przedsiębiorstw; po drugie, zależności polityczne i gospodarcze kraju; po trzecie, sytuacja gospodarstw domowych.

\section{Economical Transformation as Marginalization.}

Economical and Social Effects of Polish Times of Change

\section{Abstract}

The article presents one of the possible ways of economical transformation interpretation in Poland. Immanuel Wallerstein's theory of world-systems was used as the main point of view. The basic premise is as the marginalization of Poland on international arena was affected by neo-liberal economic way of transformation. The neo-liberal economic solutions caused also Poland's return to semi-peripheral position in the modern world-system. The analysis focuses on three factors that can confirm semi-peripheral status of Poland: ownership structure of enterprises, political and economical dependences of Poland and condition of households in Poland. 


\section{Wstęp}

Polska transformacja ustrojowa doczekała się wielu naukowych opracowań skupiających uwagę na wybranych sferach dokonujących się przemian. Wśród prac z zakresu socjologii, politologii czy ekonomii przez długi czas dominującym paradygmatem analiz był pryzmat założeń liberalnego rynku. Ostatnie lata zarówno w życiu społecznym, jak i w naukowych rozważaniach przesuwają akcent na inne możliwe kierunki interpretacji czasu przemian w Polsce. Wyczerpująca się koncepcja istniejącego ładu społecznego najwyraźniejsze odzwierciedlenie znalazła w radykalizujących się społeczeństwach Europy. Bunt przeciwko liberalnej czy też neoliberalnej formie państwa doprowadził do przejęcia władzy w wielu krajach przez skrajne partie polityczne, popierane głównie przez tych, których w Polsce przyjęło się nazywać „przegranymi transformacji", oraz młodych, którzy zostali pozbawieni perspektyw życia w rodzimym kraju.

\section{Teoria systemów-światów Immanuela Wallersteina}

Niniejszy tekst prezentuje spojrzenie na transformację ustrojową z perspektywy teorii systemów-światów Immanuela Wallersteina. Perspektywa ta daje możliwość nowego oglądu procesów zachodzących w społeczeństwie polskim po 1989 roku. Przeanalizowane zostaną procesy związane z przemianami gospodarczymi ze szczególnym uwzględnieniem roli procesu prywatyzacji. Wpisanie polskiego czasu przemian w teorię zaproponowaną przez Wallersteina umożliwia przedstawienie powrotu Polski na pozycję półperyferii w dominującej gospodarce-świecie, czyli na drogę, która wcale nie była jedyną perspektywą zmian (Sowa 2010: 25).

Wallerstein, tworząc swój teoretyczny model, czerpie między innymi z dorobku marksowskiego ujęcia formacji społecznych (imperia-światy, systemy-światy, gospodarka-świat), historycznej szkoły „Annales” (perspektywa „długiego trwania”), teorii zależności (rozwój niedorozwoju) (Starnawski, Wielgosz 2007: 15) oraz ustaleń wypracowanych przez Komisję ds. Ameryki Łacińskiej ONZ (podział świata na centrum/ rdzeń i peryferie) (Wallerstein 2007a: 33). W odróżnieniu jednak od Marksa Wallerstein przypisuje podstawową rolę akumulacji kapitału, a nie środkom produkcji. Stworzony przez niego system teoretyczny opiera się zatem na globalnym zróżnicowaniu państw narodowych na przynależące do centrum (czy też rdzenia), półperyferii oraz peryferii.

Przynależność do konkretnej grupy państw jest uzależniona od zdobytych przewag ekonomicznych, militarnych i technologicznych. Przewagi te są skutkiem tendencji samych procesów produkcyjnych o charakterze centralnym, które grupują się w kilku państwach i dominują w ich produkcji (Wallerstein 2007a: 47). O ile w centrach skupiają się wszystkie najnowocześniejsze procesy produkcyjne, o tyle peryferia stanowią rezerwuar zasobów oraz produktów niewymagających rozwiniętych technologii. 
Rola półperyferii w modelu opiera się na funkcji pośrednika pomiędzy skrajnymi grupami państw. Półperyferia, w których występują jednocześnie procesy przynależące do centrum i peryferii, przejmują gałęzie gospodarki powoli "zużywające się" w centrach, w ten sposób zachowując przewagę nad peryferiami.

Wyżej opisane relacje zachodzą w kapitalistycznej gospodarce-świecie, która stanowi obecnie funkcjonujący system-świat $\mathrm{i}-\mathrm{w}$ odróżnieniu od poprzednich systemów - jest bytem ekonomicznym, a nie politycznym (Colás 2008: 36). Kapitalistyczna gospodarka-świat dokonuje ekspansji poprzez zbrojny podbój, gospodarczą eksploatację, towarzyszy jej też masowa niesprawiedliwość społeczna (Wallerstein 2007b: 15). Wallerstein datuje początek powstawania nowoczesnego systemu-świata na tak zwany długi wiek XVI, gdy ukształtowały się zręby postulowanego przez badacza podziału pracy (Wallerstein 2004: 63).

Należy zaznaczyć również sposoby, za pomocą których współczesne państwa centrum utrzymują swoją dominującą rolę. Wallerstein przedstawia jako jeden ze sposobów "europejski uniwersalizm", który służy uzasadnieniom interwencji krajów rdzenia na obszarach kwestionujących istniejący system-świat. Interwencje takie uzasadniane są poprzez odwołania do swoistej formy uniwersalizmu, który - choć nazwany europejskim - obejmuje również chociażby Stany Zjednoczone. Analizując uzasadnienia wkraczania państw centrum $w$ kompetencje innych państw narodowych bądź też samej interwencji militarnej, Wallerstein wyodrębnia ich trzy rodzaje. Po pierwsze, polityka świata paneuropejskiego służy obronie praw człowieka i wspieraniu demokracji. Po drugie, odmiana pojawiająca się w narracji zderzenia cywilizacji, zakładającej wyższość Zachodu nad „innym”. Po trzecie, bezalternatywność rynku, który traktowany jest w kategoriach nieuchronności (Wallerstein 2007b: 12). Wszystkie te uzasadnienia łączy założona konieczność postępu rozumianego w kategoriach „nadrabiania” zaległości względem krajów centrum, a zatem niższości krajów półperyferyjnych czy peryferyjnych. Takim interwencjom towarzyszy również uzasadnienie moralne, które w zależności od okresu przyjmuje różne formy. W wieku XVI w tym celu wykorzystywano kategorie „prawa naturalnego" oraz chrześcijaństwo, w XIX stuleciu przyjęły one formę misji cywilizacyjnej, a w XX i XXI wieku praw człowieka i demokracji (Wallerstein 2007b: 42).

Warto wskazać przykładowe kraje, które w myśl teorii systemów-światów wchodzą w skład wyodrębnionych grup. Kraje centrum to przede wszystkim Stany Zjednoczone (z coraz słabszą, ale wciąż pozycją hegemona), Wielka Brytania i Niemcy. Kraje półperyferii to przykładowo Hiszpania, Norwegia i Polska. Natomiast peryferie to między innymi kraje tak zwanego Trzeciego Świata. Co ważne, pozycja danego kraju nie jest przypisana raz na zawsze. Takie kraje jak Hiszpania czy Niderlandy kiedyś były państwami centrum, a Stany Zjednoczone należały do peryferii. 


\section{Założenia metodologiczne i teoretyczne}

Metodologiczne założenia Wallersteina odwołują się do wspomnianego powyżej "długiego trwania" Fernanda Braudela, które determinuje pojmowanie zachodzących procesów historycznych w długiej perspektywie czasowej, a wydarzenia polityczne jako "kurz" historii, czyli jedynie emanacje głębszych procesów dziejowych. Odwołanie do systemowego podejścia nakazuje również umieszczać wszelkie analizy dotyczące jakiegokolwiek fragmentu rzeczywistości w szerszej perspektywie funkcjonującego systemu.

Wallerstein postuluje unidyscyplinarność nauk społecznych jako jedyną właściwą drogę ujęcia przebiegających procesów w systemie-świecie. Postulat ten oznacza łączenie perspektyw różnych nauk społecznych w celu uchwycenia właściwego obrazu badanego zjawiska.

Wytyczne metodologiczne płynące z teorii systemów-światów identyfikują wskaźniki, jakimi należy posłużyć się w podjętej problematyce. Po pierwsze, aby określić dane państwo jako półperyferie/peryferie, należy zbadać strukturę własności przedsiębiorstw. Po drugie, powinno się wskazać istniejące zależności polityczne i gospodarcze istniejącego ustroju państwowego. Po trzecie, przechodząc do skali mikro, trzeba przedstawić stan gospodarstw domowych, które w ujęciu Immanuela Wallersteina stanowią podstawową jednostkę produkowania i konsumowania przychodów. Wskazane powyżej kierunki badań wymagają wielopłaszczyznowej analizy, stąd uwaga zostanie skupiona jedynie na wybranych aspektach.

\section{Polska w kapitalistycznej gospodarce-świecie do 1989 roku}

Trzymając się założeń metodologicznych Wallersteina, należy umieścić proces polskiej transformacji ustrojowej w odpowiednim kontekście przemian historycznych istniejącego systemu-świata z perspektywy Polski.

Wiek XVI w historii Polski to czas tworzenia I Rzeczpospolitej z obowiązującym systemem demokracji szlacheckiej. W odróżnieniu od krajów zachodnioeuropejskich pozycja suwerena została ograniczona, a władzę przejęła szlachta. Na ten czas przypadł również początek pańszczyzny jako dominującej formy stosunków gospodarczych. Procesy te systematycznie prowadziły do pogłębiania się różnic pomiędzy Wschodem a Zachodem Europy, gdzie produkcję rolniczą stopniowo zastępowały handel i działalność produkcyjna (Sowa 2015: 51). Postępujący rozwój stosunków feudalnych przyczynił się ostatecznie do utwierdzenia zacofania gospodarczego względem Zachodu. Rzeczpospolita Obojga Narodów importowała wysoko przetworzone towary z państw zachodnich, a eksportowała produkty rolnicze o niskim stopniu przetworzenia. Nierówna wymiana prowadziła do coraz większego uzależniania chłopów pańszczyźnianych od szlachty poprzez pracę całych rodzin dla danego właściciela. Taki stan nie mógł się jednak utrzymywać długo. Gospodarka 
feudalna i wyidealizowana wolność szlachecka doprowadziły do niewydolności państwa pod względem ekonomicznym i militarnym, co przyczyniło się do rozbiorów. Mit Polski jako „spichlerza Europy” w tym ujęciu nie był już czynnikiem wartościującym dodatnio.

Okres zaborów to czas swoiście pojmowanej kolonizacji obszarów I Rzeczpospolitej. Rosja, Austria i Prusy podzieliły między sobą ziemie Rzeczpospolitej Obojga Narodów, stopniowo uwłaszczając chłopów i wprowadzając swoje standardy produkcji. Polska z kolonizatora stała się krajem skolonizowanym (Sowa 2011: 462).

Czas dwudziestolecia międzywojennego został poświęcony odbudowie kraju - zarówno politycznej, jak i gospodarczej. Proces ten przerwała druga wojna światowa. Następujące po niej dekady przebiegały pod dyktando wzorów gospodarczych stosowanych w Związku Socjalistycznych Republik Radzieckich. Konstytucja Polskiej Rzeczypospolitej Ludowej uchwalona przez Sejm Ustawodawczy w dniu 22 lipca 1952 r. (Dz. U. Nr 33, poz. 232) w art. 1 ustęp 1 określała ustrój państwa jako demokrację ludową. Rozdział drugi tej ustawy zasadniczej, charakteryzujący ustrój społeczno-gospodarczy, podkreślał oparcie go na "uspołecznionych środkach produkcji” (art. 7). W art. 10 z kolei państwo zobowiązywało się do ochrony i pomocy dla indywidualnych gospodarstw rolnych. Nowelizacja Konstytucji PRL z dnia 10 lutego 1976 roku (Dz. U. Nr 5, poz. 29) zmieniała treść wybranych zapisów. Polska Rzeczypospolita Ludowa została w niej przemianowana na "państwo socjalistyczne” (art. 1), a podstawę ustroju społeczno-gospodarczego stanowił "socjalistyczny system gospodarczy, oparty na uspołecznionych środkach produkcji i socjalistycznych stosunkach produkcji" (art. 7). Postanowienia zawarte w wyżej wspomnianych aktach miały charakter fasadowy i z punktu widzenia praktyki nie realizowały swoich założeń. Kapitalistyczne stosunki gospodarcze - w zależności od okresu - w mniejszym lub większym stopniu były obecne w Polsce Ludowej.

Opisany powyżej okres państwa leninowskiego Jan Sowa charakteryzuje następująco: "Stanowiło raczej specyficzną formację społeczno-ekonomiczno-polityczną, którą najtrafniej określić można jako zarządzany biurokratycznie przez nomenklaturę system państwowego kapitalizmu" (Sowa 2008: 368). W podobnym tonie utrzymane są analizy przemian własności prywatnej środków produkcji Adama Karpińskiego, który charakteryzując totalitaryzmy XX wieku, zauważa: „Socjalizm budowano w sposób kapitalistyczny" (Karpiński 2010: 77).

Odmienny charakter miała Ustawa z dnia 23 grudnia 1988 r. o działalności gospodarczej (Dz. U. Nr 41, poz. 324), która sankcjonowała istniejące stosunki ekonomiczne w kraju. W art. 1 czytamy: „Podejmowanie i prowadzenie działalności gospodarczej jest wolne i dozwolone każdemu na równych prawach...". Akt ten wyprzedzał i zapowiadał zmiany ustrojowe, które miały w kraju nastąpić w kolejnych latach. W rok później parlament uchwalił pakiet ustaw rozpoczynający transformację ustrojową. 
Ukoronowaniem przemian gospodarczych w Polsce stał się zapis w art. 20 Konstytucji Rzeczypospolitej Polskiej z dnia 2 kwietnia 1997 r. (Dz. U. Nr 78, poz. 483, ze zm.) podkreślający wolność działalności gospodarczej oraz własność prywatną jako jedne z podstaw ustroju gospodarczego kraju.

\section{Stan społeczeństwa polskiego w dobie przemian}

Społeczeństwo polskie wchodziło w nową dekadę nowego państwa z bagażem zbankrutowanej gospodarki oraz stałą niepewnością o przyszłość. Elżbieta Tarkowska, analizując orientacje temporalne Polaków w latach osiemdziesiątych ubiegłego wieku, wysunęła tezę o "społeczeństwie czekającym" jako dominującej kategorii opisującej stan zawieszenia i tymczasowości (Tarkowska 1992: 15). Tarkowska opiera swą tezę na zdiagnozowanym poczuciu permanentnego kryzysu, które towarzyszyło Polakom w trakcie dekad Polski Ludowej, i wynikającego $z$ niego zawężenia perspektyw czasowych do teraźniejszości. Dokładny stan gospodarki, który zastał nowy demokratyczny rząd, nie jest znany. Wiadomo jednak, że w bardzo szybkim tempie zdecydowano się podjąć zdecydowane kroki w celu urynkowienia gospodarki, proces ten zyskał miano „terapii szokowej”. W analizach Tarkowskiej wybór takiej formy zmian także stanowi potwierdzenie jej tezy o dominacji prezentystycznej orientacji temporalnej Polaków (Tarkowska 1992: 126). Co taka orientacja mówi nam o samym społeczeństwie doby transformacji? Otóż zawężenie takie prowadzi do ograniczenia jakości życia między innymi poprzez jego ograniczenie do poziomu organicznego, zaspokajania podstawowych potrzeb biologicznych, a także do zjawisk patologicznych: bierności, nieterminowości, rezygnacji z odległych celów, skłonności do krótkotrwałych związków społecznych oraz eskapizmu związanego z alkoholem, nieodpowiedzialnej prokreacji i konsumpcyjnego stylu życia (Tarkowska 1992: 120-121).

Polska - wraz z innymi krajami bloku wschodniego - wracała w obręb oddziaływania kapitalistycznej gospodarki-świata. Konieczność dostosowania mechanizmów rynkowych do panujących w reszcie systemu-świata objęła wszystkie strefy dotychczas państwowej gospodarki. Według Wallersteina państwa półperyferyjne mają możliwość dołączenia do krajów centrum na trzy sposoby. Po pierwsze, poprzez wykorzystanie okazji, którą stwarza na przykład kryzys ekonomiczny. Po drugie, poprzez zaproszenie, polegające na konkurencyjności pod względem prawodawstwa, mające zachęcić korporacje do inwestowania na ich terenie (Śpiewak, Jelonek 2004: 20). Trzecią drogą rozwoju jest oparcie się na własnych siłach, co oznacza niezależność gospodarczą, polityczną i kulturową (2004: 21). Polskie władze wybrały drugą z możliwości, rezygnując z uchwalonego w trakcie I Krajowego Zjazdu Delegatów NSZZ "Solidarność" programu Samorządnej Rzeczpospolitej. W dzienniku Waldemara Kuczyńskiego z lat 1989-1993 szczególnie wyraźnie przebija atmosfera pośpiechu oraz natłoku kwestii do rozwiązania przed planowaną zmianą: „Poniedziałek, 4 grudnia 1989 r. Budżet w rozsypce, opóźniają się inne materiały na KERM [Komitet Ekonomiczny Rady 
Ministrów - przyp. J.K.] [...]. Coraz większy natłok spraw i presja czasu. Nie można się nawet solidnie zapoznać z materiałami" (Kuczyński 2010: 31).

Transformację gospodarczą można jedynie umownie oddzielić od ustrojowej. Procesy te zachodziły jednocześnie i były silnie ze sobą powiązane, zmiana ustroju politycznego zakładała zmiany w gospodarce, natomiast nowe zasady funkcjonowania gospodarki prowadziły do zmian politycznych. Głównymi wyznacznikami transformacji gospodarczej w rozumieniu zmiany systemu gospodarczego są zastąpienie własności państwowej prywatną oraz centralnego planowania regulacją rynkową (Bałtowski, Miszewski 2007: 25). Tak ujęta transformacja wskazuje jednocześnie na silną rolę państwa w budowaniu nowego systemu, który stanowi zerwanie ciągłości dotąd istniejących instytucji gospodarczych. Państwo nie tylko kieruje prywatyzacją państwowych przedsiębiorstw, ale także musi stworzyć warunki dla rozwoju przedsiębiorczości obywateli. Normatywna rola władz państwowych odgrywa zasadniczą rolę $\mathrm{w}$ tych procesach.

Szczególnie interesujące są tutaj przypadki prywatyzacji przedsiębiorstw państwowych, które potencjalnie mogły konkurować z innymi zza zachodniej granicy. Przypadki te są także ciekawe ze względu na konsekwencje, które niosła za sobą kapitalistyczna racjonalizacja gospodarki i warunków pracy. Ocena tego procesu nadal budzi wiele emocji i często obciążona jest indywidualnymi sympatiami lub antypatiami.

\section{Struktura własnościowa przedsiębiorstw w Polsce w okresie transformacji}

Struktura własnościowa przedsiębiorstw w Polsce, którą odziedziczyły nowe władze, była silnie zniekształcona na rzecz wielkich przedsiębiorstw państwowych kosztem małych i średnich przedsiębiorstw oraz sektora prywatnego. Rozmijanie się produkcji państwowej z potrzebami rynku stanowiło źródło stałych niedoborów artykułów konsumpcyjnych. Z kolei przywoływana wcześniej ustawa z 23 grudnia 1988 r. o działalności gospodarczej stała się podstawą powstawania tak zwanych spółek nomenklaturowych, czyli tworzenia prywatnych spółek na bazie majątku państwowego poprzez wydzierżawianie lub przekazywanie ich majątku osobom związanym z kierownictwem przedsiębiorstw (Woźniak 2009: 34). Korupcjogenny charakter takiego powiązania władzy politycznej i rynku stał się podstawą kształtowania relacji rynkowych w Polsce. Wyzwanie, przed którym stanęli projektanci wielkiej zmiany w Polsce, dotyczyło nie tylko problemu przekształcenia potężnych przedsiębiorstw państwowych w prywatne, ale także konieczności wykształcenia się w tym procesie silnej gałęzi przedsiębiorstw małej i średniej wielkości. Pominięcie tych zależności groziło przeniesieniem struktur poprzedniej gospodarki w nowe formy, ale nie przynosiło ich zmiany. 
Polska jako jeden z nielicznych krajów postsowieckich wchodziła w proces zmian ze stosunkowo dużym sektorem prywatnym. Według danych statystycznych zatrudnionych w nim było $33 \%$ pracujących, a generował on $18 \%$ dochodu państwa (wliczając rolnictwo) (Bałtowski, Miszewski 2007: 222). W latach 1991-1994 powstały 54184 przedsiębiorstwa prywatne $z$ kapitałem państwowym oraz 2773 z kapitałem zagranicznym (2007: 225).

Pozostając jednak przy założeniu teorii systemów-światów o przewadze technologicznej krajów centrum, warto zwrócić uwagę na przedsiębiorstwa państwowe, które w wyniku prywatyzacji zostały wyeliminowane z rynku bądź których rola została sprowadzona do produkcji podzespołów. Witold Kieżun w pracy Patologia transformacji powołuje się na przygotowany w 1996 roku przez zespół ekonomistów raport O potrzebie długofalowej strategii w stosunku do kapitału zagranicznego w Polsce' (Kieżun 2013: 135). Raport ten przedstawia między innymi wpływ otwarcia rynku dla zagranicznego kapitału w latach 1990-1993 na zmiany w produkcji produktów wysokiej techniki. Według tych danych w omawianym okresie produkcja aparatury informatycznej spadła o 26,1\%, aparatury optycznej o 36,6\%, maszyn i urządzeń energetycznych o 44,9\%, urządzeń elektronicznych i teletechnicznych o 66,7\% (Kieżun 2013: 138). Dane te poprzedzone są przykładami polskich przedsiębiorstw, które zostały wykupione przez kapitał zagraniczny. Przykładowo Zakłady Wytwórcze Urządzeń Telefonicznych ZWUT (Warszawa, Węgrowo, Bydgoszcz) oraz Zakład Komputerowy ELWRO (Wrocław) zostały wykupione przez firmę Siemens, a następnie zlikwidowane, choć ich wyniki ekonomiczne były dobre. Przejęcie przedsiębiorstw państwowych przez kapitał zagraniczny nie zawsze jednak kończyło się likwidacją zakładu. Wykupienie 80\% akcji Zakładów Produkcji Papieru i Celulozy w Kwidzynie w 1990 roku przez International Paper Group INC wraz z paroletnim zwolnieniem z obowiązku podatkowego stanowiło z kolei przykład marnotrawstwa przekraczającego normy akceptacji społecznej (Kieżun 2013: 138, 140). Pamiętając o tych danych, warto zauważyć, że w 2012 roku Polska zajmowała 23. miejsce na 27 krajów Unii Europejskiej w dziedzinie wydatków na innowacje (badania i rozwój) w wysokości 0,68\% swojego PKB (średnia w Unii Europejskiej wynosi 2\%) (Lewicki 2012: 520).

Postępowanie takie mieści się w logice kapitalistycznej gospodarki-świata, która jest bezwzględna w dążeniu do akumulacji kapitału. Przejmowanie kontroli nad najbardziej dochodowymi gałęziami produkcji, którymi bez wątpienia są te z zakresu nowych technologii, stanowi formę kontroli i zabezpieczenia przed niechcianą konkurencją. Jak wspomniano, decydenci sami wybrali drogę zaproszenia zagranicznych korporacji w celu "odrobienia strat" względem mitycznego Zachodu, by w perspektywie znaleźć się w gronie państw centrum. Oczywiście ciężko w takim przypadku mówić o świadomym wyborze, jednak fakt przystąpienia do "nadganiania” oraz dominujący w myśleniu o transformacji czynnik bezalternatywności kapitalistycznej

${ }^{1}$ Raport ten nigdy nie został upubliczniony w całości. 
formy rynku („europejskiego uniwersalizmu”) stanowią przykłady zdominowania innych form przez neoliberalną narrację.

Według Kieżuna Polska znowu została skolonizowana, tym razem nie za pomocą siły militarnej innego państwa, ale przez zagraniczne korporacje przy użyciu kapitału. Katastroficzną wizję badacza łagodzi fakt, że Polska według badań Organizacji Współpracy Gospodarczej i Rozwoju (OECD)² ma nie tylko jeden z największych sektorów państwowych spośród innych krajów postsowieckich, ale także stopień bezpośredniej kontroli nad przedsiębiorstwem pośród krajów członkowskich, co według logiki istniejącego systemu wcale nie jest zaletą (Kozarzewski 2013: 118).

Teza o kolonizacji Polski przez zagraniczne korporacje często pojawia się w dyskusjach nad stanem gospodarki i społeczeństwa. Zainteresowała ona również wielu badaczy. Alexander Kiossev interpretuje ten proces jako samokolonizację, czyli ukształtowanie tożsamości narodowej poprzez traumę niższości wynikającą ze świadomości wyobcowania. Trauma ta powoduje poczucie bycia rezerwuarem zacofania oraz zbyt późnego pojawienia się na arenie międzynarodowej (Sowa 2011: 20). Interpretacja ta nasuwa skojarzenia z frommowską "ucieczką od wolności”, społeczeństwo nie chce samo dźwigać ciężaru decyzji i odpowiedzialności, więc szuka hegemona i importuje rozwiązania nieprzystające do warunków historycznych, społecznych lub gospodarczych.

\section{Polityczne i gospodarcze wymiary „nadrabiania"}

Międzynarodowe oddziaływania na formę i kierunek zmian w pierwszej połowie lat dziewięćdziesiątych w Polsce warto poprzedzić krótkim przypomnieniem funkcjonującego w społeczeństwie polskim mitu Zachodu. Pozwoli to w pewnym stopniu wyjaśnić, dlaczego Polacy tak bardzo i w tak szybkim tempie chcieli opuścić wschodnie rubieże Europy. Wspomniana wcześniej samokolonizacja Kiosseva idealnie wpisuje się w poczucie niższości względem państw zachodnich. O tym, jak społeczne wyobrażenia (szczególnie te fałszywe) na temat danych regionów świata oddziałują na ich oceny i dalsze losy, pisali już między innymi Edward Said (2005) oraz Maria Todorova (2008).

Janine Wedel w następujący sposób opisała, czym dla Polaków w latach osiemdziesiątych ubiegłego wieku był Zachód: „Wielu Polaków pożąda kojarzonych z Zachodem dóbr materialnych i szerokich możliwości, jednak prosperity po polsku ma swoje ideały. Wyobrażalny świat materialny, do którego aspirują Polacy, to ciasto w proszku, papierosy Marlboro i Paris Match" (Wedel 2007: 107). Cytat ten skupia się na wymiarze materialnym, jednak znacznie ważniejsze są jego konotacje w sferze mentalności. Wschód dla Polaków stanowił i stanowi synonim zacofania, natomiast Zachód postępu i nowoczesności. Zachód to także symbol "normalności”, do której należy

${ }^{2} \mathrm{OECD}$ - skrót od anglojęzycznej nazwy: Organization for Economic Co-operation and Development. 
dążyć i ostatecznie osiągnąć. Budowana na zasadzie opozycji Wschód-Zachód tożsamość społeczeństwa skutkuje negacją tego, co niechciane (zastane), oraz - po raz kolejny - przyjmowaniem wzorów nieprzystających do rzeczywistości. Oczywiście jest to jeden z wymiarów tożsamości Europy Wschodniej, która stanowi twór hybrydalny.

Ukształtowany przez lata niedoboru, widziany jedynie z perspektywy widza, świat zachodni mamił i obiecywał styl życia, którego statystyczny Polak mógł nigdy nie osiągnąć. Według danych Centrum Badań Opinii Społecznej (CBOS) w 1992 roku aż 88\% Polaków uważało, że "typowy Europejczyk żyje w dobrych warunkach", gdy warunki życia "typowego Polaka" za dobre uznało jedynie 13\% respondentów (Tomasik, Zielińska 2012: 476). Taki obraz zachodniego społeczeństwa jako punktu porównań stanowi wyraz opisanego przez Wallersteina "europejskiego uniwersalizmu" przekonującego o konieczności zmiany w konkretnym kierunku (demokracja, kapitalizm) oraz jednocześnie legitymizującego ten kierunek poprzez kategorię postępu.

Przywoływany wcześniej dziennik Waldemara Kuczyńskiego zawiera opis postawy Międzynarodowego Funduszu Walutowego (MFW) wobec przygotowanego budżetu: „Niedziela, 3 grudnia 1989 r. [...] 15 grudnia MFW wyda oświadczenie, że program jest zaakceptowany, ale wymaga zmian budżetu w kierunku zaostrzenia, i chce widzieć budżet z wyodrębnieniem z niego I kwartału, a nawet z rozbiciem na styczeń i luty. Eksperci MFW mówią też, że za mało jest w budżecie rezerw" (Kuczyński 2010: 31). Słowa te pokazują nie tylko uzależnienie państwa od organizacji międzynarodowej i jej ekspertów, ale także stopień zaangażowania w spełnienie ich oczekiwań. Należy zastrzec, że choć dziennik daje wgląd w procesy decyzyjne prowadzące do transformacji, nie można traktować go jako ostatecznej instancji rozstrzygającej o przebiegu wielkiej zmiany.

Aspiracje do przynależenia do kręgu państw zachodnich prowadziły do konieczności nawiązania współpracy i kontaktów na arenie międzynarodowej. Jedną z pierwszych ponadnarodowych instytucji, do której przyłączyła się w trakcie transformacji Polska, była Inicjatywa Środkowoeuropejska, która stawiała sobie za cel między innymi ułatwienie krajom byłego bloku wschodniego współpracy z Zachodem. W tym samym - 1991 - roku Polska dołączyła do krajów tworzących Radę Europy. W 1995 roku Polska dołączyła do Światowej Organizacji Handlu (WTO), rok później do Organizacji Współpracy Gospodarczej i Rozwoju (OECD), w 1999 roku do NATO, a w 2004 roku weszła w struktury Unii Europejskiej. Wśród różnych, często rozbieżnych, opinii na temat końca okresu transformacji za datę jej zakończenia często uważa się moment wstąpienia do Unii Europejskiej. Polska brała również czynny udział w tworzeniu nowych nieformalnych grup o zasięgu międzynarodowym, między innymi Grupy Wyszehradzkiej oraz Trójkąta Weimarskiego (obie powołano do życia w 1991 roku). Wszystkie te organizacje sformułowały wstępne wymagania względem kandydatów do członkostwa. 
Szczególnie ważnym ze względu na wpływ na prawodawstwo oraz ekonomię państwa jest proces akcesji do Unii Europejskiej, który rozpoczął się od złożenia wniosku o stowarzyszenie ze Wspólnotą Europejską w 1990 roku oraz związana z nim europeizacja kraju. Czternaście lat negocjacji oraz weryfikacji wprowadzania kolejnych zmian zakończyło się wejściem Polski w struktury Unii wraz z dziewięcioma innymi państwami. Proces poszerzania Unii krytykowano głównie za dyskurs „wymagań" stawianych kandydatom, „w którym doszukiwano się imperialnych tendencji do ignorowania słabszych partnerów i w praktyce bezdyskusyjnego narzucania krajom peryferyjnych arbitralnych unijnych norm" (Zarycki 2009: 210). Spełnienie stawianych przez Unię oczekiwań, wśród których najważniejszym było dostosowanie systemu prawnego, kierowało rozwojem państw-kandydatów, choć nie brano pod uwagę specyfiki krajów postkomunistycznych i kształtowano je na podstawie założenia o powszechności problemów rozwojowych (2009: 210).

„Umiędzynarodowienie" Polski miało jednak jeszcze za zadanie budowę jej wizerunku jako kraju o stabilnych podstawach gospodarczych i politycznych, a zatem stworzenia z niej produktu, marki - jednym słowem urynkowieniu. Taki obraz z kolei sprzyjał napływowi nowych zagranicznych inwestycji, dla których stabilność polityczna regionu stanowi jeden z podstawowych czynników zabezpieczenia kapitału.

Akumulacja kapitału będąca podstawą funkcjonowania kapitalistycznej gospodarki-świata wymaga obniżania kosztów związanych z produkcją szeroko rozumianych dóbr. Państwo może wpływać na decyzje o zainwestowaniu przez dane przedsiębiorstwo na swoim terytorium poprzez tworzenie odpowiednich aktów prawnych, tanią siłę roboczą oraz ponoszenie części kosztów. Takie rozumowanie prowadzi do wyodrębnienia niesprzyjających dla kapitalistów warunków działania rynku. Po pierwsze, całkowicie wolny rynek nie leży w interesie przedsiębiorców, gdyż zaostrza konkurencję, a tym samym ogranicza ich przychody (Wallerstein 2004: 93). Stąd ograniczone monopole tworzone przez państwa narodowe najlepiej sprzyjają akumulacji kapitału. Po drugie, demokratyzacja, prowadząca do upowszechnienia praw pracowniczych oraz wzrostu płac, podnosi koszty produkcji. Dlatego międzynarodowe korporacje eksportują produkcję do krajów peryferyjnych, gdzie koszt pracy robotnika stanowi ułamek ceny wyprodukowanego dobra. Trzecim warunkiem są wysokie podatki oraz brak partycypacji w tworzeniu dogodnej dla produkcji infrastruktury (na przykład autostrad) (2004: 95). Polska w trakcie transformacji spełniała przynajmniej dwa z trzech czynników, dysponowała tanią siłą roboczą oraz po preferencyjnych warunkach (cena stanowiąca procent wartości zakładu pracy, "wakacje podatkowe") prywatyzowała państwowe przedsiębiorstwa.

Strategia wprowadzenia kraju w międzynarodowe struktury oraz wpływ tych struktur na funkcjonowanie państwa coraz silniej zakorzeniały je w funkcjonowaniu kapitalistycznej gospodarki-świata. Jane Hardy następującymi słowami opisała proces "umiędzynarodowiania" Polski w omawianym okresie: 
Wysiłki organizacji międzynarodowych, Stanów Zjednoczonych i Unii Europejskiej, wsparte przez mnóstwo innych inicjatyw, złożyły się w bezprecedensową kampanię na rzecz rozszerzania i konsolidacji neoliberalnej hegemonii pod płaszczykiem restrukturyzacji owych gospodarek [krajów postsowieckich - przyp. J.K.] i ich integrowania z gospodarką światową (Hardy 2012: 115).

\section{Gospodarstwa domowe}

Ostatni z czynników, który może świadczyć o półperyferyjnej pozycji kraju w systemie-świecie, jest związany z funkcjonowaniem gospodarstw domowych, a dokładnie ze zjawiskami mogącymi prowadzić do decyzji o emigracji zarobkowej. Wallerstein przypisuje gospodarstwom domowym głównie rolę ekonomiczną, gdyż ma ona niejako zobowiązywać swoich członków do wytwarzania dochodu, jednocześnie umożliwiając im jego wspólną konsumpcję (Wallerstein 2007a: 52). W myśl teorii Wallersteina kraje półperyferyjne i peryferyjne stanowią rezerwuar taniej siły roboczej oraz surowców. Stąd należy prześledzić takie wskaźniki jak stopa bezrobocia oraz migracje ekonomiczne Polaków, których współwystępowanie mogłoby świadczyć o prawdziwości tezy Wallersteina w odniesieniu do Polski.

W latach 1990-2002 można wyodrębnić trzy okresy narastania bezrobocia rejestrowanego. Pierwszy okres to lata 1990-1993, kiedy nastąpił gwałtowny wzrost o 2,6 mln osób; drugi okres to lata 1994-1998, kiedy nastąpił spadek o ponad 1,1 mln osób; trzeci okres to lata 1999-2002, kiedy znowu nastąpił wzrost, tym razem o 1,3 mln osób. Statystyki te nie obejmują między innymi ukrytego bezrobocia w rolnictwie szacowanego na 0,8-1 mln osób (Kabaj, Danecka 2005: 116). Według danych Głównego Urzędu Statystycznego w wyodrębnionych okresach procentowa dynamika wzrostu bezrobocia w Polsce wyglądała następująco: w latach 1990-1993 wzrost z 6,5\% do 16,4\%, w latach 1994-1998 spadek z 16\% do 10,4\%, w latach 1999 2002 wzrost z 13,1\% do, w zależności od źródła, 18 lub 20\% (Stopa bezrobocia... 2016). Pierwszy wyróżniony okres przypada na najwcześniejsze lata transformacji - wskaźniki lawinowego wzrostu bezrobocia wiążą się z tym, że w poprzednim systemie było ono ukryte. Postępujące procesy prywatyzacji oraz wolność w prowadzeniu działalności gospodarczej skutkowały zmniejszeniem liczby osób bezrobotnych w drugim okresie, aby w trzecim, podczas którego wygasły gwarancje zatrudnienia w sprywatyzowanych przedsiębiorstwach państwowych, znowu gwałtownie wzrosnąć. Przedstawione dane statystyczne, choć unaoczniają skalę zjawiska z perspektywy kraju, nie oddają zróżnicowania zjawiska bezrobocia ze względu na odmienności regionalne, płeć czy też wiek. W kwietniu 2004 roku, czyli przed samym wstąpieniem Polski w struktury Unii Europejskiej, stopa bezrobocia wynosiła 19,9\% (Stopa bezrobocia... 2016).

Omawiany okres to także czas migracji Polaków, którego saldo jest ujemne. Utrzymując wcześniej przyjęty podział, w latach 1990-1993 z Polski wyemigrowało łącznie 78908 osób, w latach 1994-1998 115944 osoby, natomiast w okresie od 1999 do 
2002 roku włącznie 96435 (Główne kierunki emigracji i imigracji... 2015). Powyższe dane odnoszą się do emigracji na pobyt stały, a ich łączna liczba wskazuje 291287 osób wyjeżdżających z Polski, to jest ponad 22 tys. osób rocznie. Głównymi krajami docelowymi migracji były Niemcy, Wielka Brytania, Stany Zjednoczone, Kanada i Irlandia (Główne kierunki emigracji i imigracji... 2015), czyli w większości kraje, które w kapitalistycznej gospodarce-świecie stanowią centrum. Proces ekonomicznej emigracji nasilił się szczególnie po wstąpieniu Polski do Unii Europejskiej, które umożliwiło swobodny przepływ ludności. Główną motywację wychodźców stanowiła chęć poprawy warunków życia i - co bardziej symptomatyczne - często była to jedyna szansa do wejścia na rynek pracy ludzi młodych.

W kontekście bezrobocia oraz emigracji zarobkowej warto zwrócić uwagę na polaryzację wysokości dochodów Polaków, co również jest elementem wskazującym na półperyferyjność kraju. Elity w krajach półperyferyjnych często same osiągają standard i poziom życia krajów centrum, gdy reszta społeczeństwa się od nich oddala (Zarycki 2009: 34). W 2000 roku 20\% najbogatszych Polaków zarabiało 4,7 raza więcej niż 20\% najmniej zarabiających. Stosunek ten powiększył się do 6,6 w 2005 roku (Hardy 2012: 198-199).

\section{Podsumowanie}

Przedstawione czynniki wpisują Polskę w grupę krajów półperyferyjnych zgodnie z tezą Immanuela Wallersteina, co de facto świadczy o jej marginalizacji. Okres tak zwanego komunizmu w Polsce stanowił czas wyrwania kraju z większości wpływów dominującej kapitalistycznej gospodarki-świata, natomiast zmiany po 1989 roku to proces powrotu na wcześniej zajmowaną pozycję. Przebudowa gospodarcza czasu transformacji w neoliberalnym duchu przyniosła zarówno pozytywne, jak i negatywne skutki. Napływ zagranicznego kapitału umożliwił poprawę warunków życia, ale także przyczynił się do ograniczenia praw pracowniczych oraz bezrobocia, a to z kolei do masowej emigracji. Prowadzona polityka pod dyktando "postępu” wyklucza szerokie rzesze osób z możliwych korzyści.

Ekonomiczne zacięcie Wallersteina skupia się na czynnikach gospodarczych, jednak docenia on holistyczną perspektywę, za sprawą której w jego teorii łączą się różne dziedziny nauk społecznych. Anna Sosnowska, analizując fenomen zacofania Europy Wschodniej, klasyfikuje teorię Wallersteina pośród tych, które umieszczają rozwój Europy Wschodniej w pozycji zależności od Zachodniej (Sosnowska 2004).

Paradygmat Wallersteina cały czas ewoluuje i stąd wynikają jego pewne niespójności, jednak daje on możliwość spojrzenia na zachodzące współcześnie procesy z perspektywy diametralnie odbiegającej od dominującego dyskursu. 


\section{Literatura}

Bałtowski M., Miszewski M., 2007, Transformacja gospodarcza w Polsce, Warszawa: Wydawnictwo Naukowe PWN.

Colás A., 2008, Imperium, tłum. J. Dobrowolski, Warszawa: Sic!

Główne kierunki emigracji i imigracji w latach 1966-2014 (migracje na pobyt stały), 2015, Główny Urząd Statystyczny, http://stat.gov.pl/obszary-tematyczne/ludnosc/migracje-ludnosci/glowne-kierunki-emigracji-i-imigracji-w-latach-1966-2014-migracje-na-pobyt-staly,4,1.html [dostęp: 8.06.2016].

Hardy J., 2012, Nowy polski kapitalizm, tłum. A. Czarnacka, Warszawa: Książka i Prasa.

Kabaj M., Danecka M., 2005, Bezrobocie i pomoc społeczna [w:] Wygrani i przegrani polskiej transformacji, red. M. Jarosz, Warszawa: Oficyna Naukowa, Instytut Studiów Politycznych PAN.

Karpiński A. J., 2010, Prywatna własność środków produkcji. Od ojcobójstwa do syna marnotrawnego, Gdańsk: Wydawnictwo Gdańskiej Wyższej Szkoły Administracji.

Kieżun W., 2013, Patologia transformacji, Warszawa: Poltext.

Kozarzewski P., 2013, Prywatyzacja. Sprzeczności i konflikty [w:] Polskie bieguny. Społeczeństwo w czasach kryzysu, red. M. Jarosz, Warszawa: Oficyna Naukowa, Instytut Studiów Politycznych PAN.

Kuczyński W., 2010, Solidarność u władzy. Dziennik 1989-1993, Gdańsk: Europejskie Centrum Solidarności.

Lewicki M., 2012, Rozwój gospodarczy i zachowania ekonomiczne [w:] Współczesne społeczeństwo polskie, red. A. Giza, M. Sikorska, Warszawa: Wydawnictwo Naukowe PWN.

Said E.W., 2005, Orientalizm, tłum. M. Wyrwas-Wiśniewska, Poznań: Zysk i S-ka.

Sosnowska A., 2004, Zrozumieć zacofanie. Spory historyków o Europę Wschodniq (1947-1994), Warszawa: Trio.

Sowa J., 2008, Ciesz się, późny wnuku! Kolonializm, globalizacja i demokracja radykalna, Kraków: Korporacja Ha!art.

Sowa J., 2010, Mitologie III RP. Ideologiczne podstawy polskiej transformacji [w:] Podziały klasowe i nierówności społeczne. Refleksje socjologiczne po dwóch dekadach realnego kapitalizmu w Polsce, red. P. Żuk, Warszawa: Oficyna Naukowa.

Sowa J., 2011, Fantomowe ciało króla. Peryferyjne zmagania z nowoczesną formq, Kraków: Universitas. Sowa J., 2015, Inna Rzeczpospolita jest możliwa! Widma przeszłości, wizje przyszłości, Warszawa: WAB. Starnawski M., Wielgosz P., 2007, Kapitalizm nad przepaściq, społeczeństwo wobec wyboru. O krytycznych perspektywach analizy systemów-światów Immanuela Wallersteina [w:] I. Wallerstein, Analiza systemów-światów. Wprowadzenie, tłum. K. Gawlicz, M. Starnawski, przedm. M. Starnawski, P. Wielgosz, Warszawa: Wydawnictwo Akademickie Dialog.

Stopa bezrobocia w latach 1990-2016, 2016, Główny Urząd Statystyczny, http://stat.gov.pl/obszary-tematyczne/rynek-pracy/bezrobocie-rejestrowane/stopa-bezrobocia-w-latach-1990-2016,4,1. html [dostęp: 8.06.2016]

Śpiewak P., Jelonek A.W., 2004, Immanuel Wallerstein i jego paradygmat [w:] I. Wallerstein, Koniec świata, jaki znamy, tłum. M. Bilewicz, A.W. Jelonek, K. Tyszka, Warszawa: Wydawnictwo Naukowe Scholar.

Tarkowska E., 1992, Czas w życiu Polaków. Wyniki badań, hipotezy, impresje, Warszawa: Polska Akademia Nauk, Instytut Filozofii i Socjologii.

Todorova M., 2008, Bałkany wyobrażone, tłum. P. Szymor, M. Budzińska, Wołowiec: Wydawnictwo Czarne. 
Tomasik M., Zieleńska M., 2012, Polska w Unii Europejskiej [w:] Współczesne społeczeństwo polskie, red. A. Giza, M. Sikorska, Warszawa: Wydawnictwo Naukowe PWN.

Wallerstein I., 2004, Koniec świata, jaki znamy, tłum. M. Bilewicz, A.W. Jelonek, K. Tyszka, Warszawa: Wydawnictwo Naukowe Scholar.

Wallerstein I., 2007a, Analiza systemów-światów. Wprowadzenie, tłum. K. Gawlicz, M. Starnawski, przedm. M. Starnawski, P. Wielgosz, Warszawa: Wydawnictwo Naukowe Scholar.

Wallerstein I., 2007b, Europejski uniwersalizm. Retoryka władzy, tłum. A. Ostolski, Warszawa: Wydawnictwo Naukowe Scholar.

Wedel J.R., 2007, Prywatna Polska, tłum. S. Kowalski, przedm. J. Kurczewski, Warszawa: Trio.

Woźniak M.G., 2009, Zmiany strukturalne gospodarki Polski po 1990 roku, „Prace Komisji Geografii Przemysłu Polskiego Towarzystwa Geograficznego", nr 12.

Zarycki T., 2009, Peryferie. Nowe ujęcia zależności centro-peryferyjnych, Warszawa: Wydawnictwo Naukowe Scholar.

\section{Źródła prawa}

Konstytucja Polskiej Rzeczypospolitej Ludowej uchwalona przez Sejm Ustawodawczy w dniu 22 lipca 1952 r. (Dz. U. Nr 33, poz. 232).

Konstytucja Rzeczypospolitej Polskiej z dnia 2 kwietnia 1997 r. (Dz. U. Nr 78, poz. 483, ze zm.).

Ustawa z dnia 10 lutego 1976 r. o zmianie Konstytucji Polskiej Rzeczypospolitej Ludowej (Dz. U. Nr 5 , poz. 29).

Ustawa z dnia 23 grudnia 1988 r. o działalności gospodarczej (Dz. U. Nr 41, poz. 324). 